\title{
Unified educational space of the EAEU member states
}

\author{
Irina B. Stukalova ${ }^{1 *}$, Anastasia A. Stukalova ${ }^{2}$, and Anatoliy V. Shishkin ${ }^{2}$ \\ ${ }^{1}$ Plekhanov Russian University of Economics, Department of Trade Policy, Moscow, Russia \\ ${ }^{2}$ Plekhanov Russian University of Economics, Department of Marketing, Moscow, Russia
}

\begin{abstract}
The article deals with the issues of integration of individual national educational systems and the formation of a single Eurasian educational space. The purpose of the article is to assess the degree of readiness of the national higher education systems of the Eurasian Economic Union (EAEU) member states for consistent integration. The assessment was conducted employing the tools of mathematical statistics. At the first stage, the authors formalized the national education system parameters in the form of a scorecard. At the second stage of the study, a comparative analysis of educational systems was carried out based on enlarged groups of quantitative and qualitative indicators. To conduct a comparative analysis of educational systems the authors used comparative logical, descriptive, and cluster analysis methods. According to the analysis results, Armenia and Belarus turned out to be the countries, most close to each other in terms of the totality of qualitative and quantitative indicators of national higher education systems. The conducted analysis allows concluding that Belarus can integrate with other countries most easily. Armenia is ranked the second country capable of such integration. Kazakhstan and Kyrgyzstan are in the third and fourth places, respectively. According to the results of the cluster analysis, Russia has shown a minimal degree of integration of the higher education system with other EAEU countries, as it is the leader in terms of several qualitative and quantitative indicators. The authors have empirically proved that the EAEU member states have similar approaches to the organization of the higher education system and can hypothetically be united into a single educational cluster within a single Eurasian educational space. Keywords: a national system of higher education, integration, EAEU, common educational space.
\end{abstract}

\section{Introduction}

In recent years, several studies have appeared on the formation of a single educational space, globalization, and internationalization of the education sector [1-6]. The sphere of researchers' scientific interest also includes the prerequisites of integration processes [7]. However, the analysis and assessment of the prerequisites formedness and conditions for forming a single educational space are mainly descriptive. Currently, the most popular quantitative characteristics of integration processes among researchers are the indicators of

\footnotetext{
${ }^{*}$ Corresponding author: stukalova.ib@rea.ru
} 
internationalization in the field of education, which assess the academic mobility of students and teachers [8-11]. In recent publications, the authors have used specific quantitative parameters to quantify the level of internationalization that underlies integration processes, such as the number of students participating in educational integration, the number of joint educational programs, and/or the number of universities involved in network-based university [12-14]. In this regard, an attempt to assess the degree of integration of individual national educational systems and the formation of a single educational space using mathematical and statistical tools seems to be quite relevant.

\section{Problem statement}

The purpose of the present article is to assess using cluster analysis methods the possibility of forming a single Eurasian educational space by assessing the degree of readiness of national higher education systems for consistent integration. The educational systems of Russia, Belarus, Kazakhstan, Armenia, and Kyrgyzstan, which are the member states of the Eurasian Economic Union (EAEU) and, at the same time, the member states of the Commonwealth of Independent States (CIS), were identified as the object of comparative analysis. At first glance, the EAEU member states have serious conditions for comparability, and prerequisites for the subsequent integration of their educational systems. First, they have been formed based on a single Soviet educational foundation. While the EU member states are united by a single European civilizational idea, culture, and religion, the CIS and/or EAEU states are united by the common education system created in the Soviet period, the common problems associated with the transition to a tier-based system of higher education, and the formation of a nonstate education sector, as well as the implementation of market elements in the activities of educational organizations. Secondly, all the above-mentioned states are participants of the Bologna Process $[15,16]$. The educational systems of the independent states were developed over almost three decades, influenced by the peculiarities of the national educational policy, the development level of the national economy, and the different pace of development. Currently, the educational system of each state has its specific configuration, different quantitative and qualitative parameters, as well as the development level of integration prerequisites and conditions.

\section{Assessment of the readiness of the national higher education systems of EAEU member states for integration}

To conduct the study, the authors used a methodology consisting of several stages. The main task at the first stage was to formalize the national education systems parameters and develop a scorecard for the comparative analysis of higher education systems in different countries, including several qualitative and quantitative characteristics (Table 1).

Table 1. The scorecard for the analysis of higher education systems of the EAEU countries.

\begin{tabular}{|c|l|}
\hline No & \multicolumn{1}{c|}{ Indicators } \\
\hline \multicolumn{1}{|c|}{ Organizational and legal indicators } \\
\hline 1.1 & \multicolumn{1}{|c|}{ Availability of a relevant ministry } \\
\hline 1.2 & $\begin{array}{l}\text { Availability of state licensing and accreditation procedures for higher } \\
\text { education programs }\end{array}$ \\
\hline 1.3 & $\begin{array}{l}\text { The possibility of receiving higher education on a budgetary and/or } \\
\text { extrabudgetary basis }\end{array}$ \\
\hline 1.4 & Availability of state educational standards of higher education \\
\hline
\end{tabular}




\begin{tabular}{|c|c|}
\hline 1.5 & $\begin{array}{l}\text { Availability of a national qualifications framework and/or professional } \\
\text { standards }\end{array}$ \\
\hline 1.6 & $\begin{array}{l}\text { Availability of intergovernmental agreements on the recognition of } \\
\text { degrees, titles, and educational certificates }\end{array}$ \\
\hline 1.7 & Education language defined by national legislation \\
\hline 1.8 & $\begin{array}{l}\text { Availability of tier-based education (Bachelor's degree, Specialist's } \\
\text { degree, Master's degree) }\end{array}$ \\
\hline 1.9 & Terms and forms of receiving higher education \\
\hline 1.10 & Use of the Ph.D. degree \\
\hline 1.11 & $\begin{array}{l}\text { Participation of the country's leading universities in the world academic } \\
\text { rankings }\end{array}$ \\
\hline & 2. Quantitative characteristics block \\
\hline & Socio-demographic indicators \\
\hline 2.1 & Number of higher education institutions \\
\hline 2.2 & Number of higher education institutions per 10,000 population \\
\hline 2.3 & Number of students involved in higher education programs \\
\hline 2.4 & $\begin{array}{l}\text { Admission to higher education programs: Bachelor's degree programs, } \\
\text { Specialist's degree programs, Master's degree programs in the forms of } \\
\text { education }\end{array}$ \\
\hline 2.5 & $\begin{array}{l}\text { Number of graduates (bachelors, specialists, masters) by various forms of } \\
\text { study }\end{array}$ \\
\hline 2.6 & $\begin{array}{l}\text { The proportion of students in the country's population enrolled in higher } \\
\text { education programs, } \%\end{array}$ \\
\hline 2.7 & $\begin{array}{l}\text { Structure of the number of students enrolled in educational programs of } \\
\text { higher education - Bachelor's degree programs, Specialist's degree } \\
\text { programs, Master's degree programs, by program modes, } \%\end{array}$ \\
\hline 2.8 & The proportion of postgraduates in the population of the country, $\%$ \\
\hline 2.9 & $\begin{array}{l}\text { The number of foreign students enrolled in educational programs of higher } \\
\text { education }\end{array}$ \\
\hline 2.10 & $\begin{array}{l}\text { The proportion of foreign students of higher education institutions in the } \\
\text { total number of students in the country, } \%\end{array}$ \\
\hline 2.11 & Structure of the number of foreign students by major countries, $\%$ \\
\hline 2.12 & $\begin{array}{l}\text { The proportion of the adult population with higher education in the } \\
\text { country's total population, } \%\end{array}$ \\
\hline \multicolumn{2}{|r|}{ Indicators of financial, labor, information, material and technical recourses } \\
\hline 2.13 & The proportion of expenditures on education in the country's budget, \% \\
\hline 2.14 & $\begin{array}{l}\text { The proportion of expenditures on higher education in the country's } \\
\text { budget, \% }\end{array}$ \\
\hline 2.15 & The proportion of expenditures on education in GDP, $\%$ \\
\hline 2.16 & The proportion of expenditures on higher education in GDP, $\%$ \\
\hline 2.17 & $\begin{array}{l}\text { Number of the teaching staff of educational institutions of higher } \\
\text { education }\end{array}$ \\
\hline
\end{tabular}

Source: Compiled by the authors

The block of qualitative indicators characterized the organizational and legal basis for building the system of higher and postgraduate education in the country. The block of quantitative indicators allowed determining the quantitative parameters of the national education system and assessing the formation of conditions to implement the geopolitical and economic prerequisites of integration in a particular country.

A comparative analysis of educational systems was carried out by enlarged groups of indicators at the second stage of the study.

1) Analysis of quality indicators. To ensure the comparability of the comparative analysis results, the qualitative indicators were transformed into quantitative ones. For Russia, as a country with the reference parameters, used to assess the potential compatibility of other 
states, all indicators were assigned a unit value. The qualitative characteristics of other countries were assigned quantitative values within the range from zero to one, using the expert method. The experts were the research and teaching staff of Moscow universities, who demonstrated a high degree of consistency in their opinions. When analyzing the qualitative characteristics, it was concluded that, in general, the studied EAEU countries had similar higher education systems, since each of them had a relevant ministry in charge dealing with higher education issues, as well as each country had also procedures for accreditation and licensing of higher education institutions; in most countries teaching was conducted in Russian, or Russian was studied as a foreign language. All EAEU countries were consistently making the transition to a tiered education system, namely, Bachelor's degree and Master's degree programs. The main differences were the international academic rankings ${ }^{\dagger}$ given to various universities of each of the countries, as well as the number of agreements on the recognition of diplomas and scientific degrees with other countries. According to these parameters, Russia was the obvious leader, while Belarus and Kazakhstan shared the second and third places.

2) Analysis of quantitative indicators. When analyzing quantitative indicators for the comparability of data, the latter were normalized per country's population. The comparative analysis of quantitative indicators was carried out based on the values of variation coefficient, which ranged from 30 to almost $100 \%$. Such a scatter of the variation coefficient indicated significant differences in quantitative indicators, as opposed to qualitative ones. Nevertheless, as a result of a comparative analysis of quantitative parameters, it turned out that Kazakhstan and Armenia were the closest to Russia in terms of education systems.

3) Cluster analysis. At the final stage of the study, the STATISTICA program was employed, which allowed analyzing qualitative and quantitative indicators that made it possible to unite the EAEU states into clusters. The software function of data standardization was used to ensure comparability. According to the results of the k-means cluster analysis, Armenia and Belarus can be combined into a single cluster, while Russia, Kazakhstan, and Kyrgyzstan should be separated into individual independent clusters (Fig. 1).

The employment of the principal component cluster analysis method made it possible to construct a three-dimensional scattering diagram (Fig. 2). According to the analysis results, Armenia and Belarus are the closest countries to each other in terms of the entire set of qualitative and quantitative indicators of national higher education systems. The assessment of the average distances* between the points denoting the countries allows concluding that Belarus integrates with other countries most easily (the distance from the point symbolizing Belarus to other countries is minimal). Armenia ranks second in terms of integration capability. Kazakhstan and Kyrgyzstan rank third and fourth, respectively. According to the results of the cluster analysis, Russia shows a minimal degree of integration capability of the higher education system with other EAEU countries, since it is the leader in terms of several qualitative and quantitative indicators.

\footnotetext{
$\dagger$ Russia ranked first with the largest number of universities (27) that were included in the TOP-1000 universities according to the QS rating for 2018; the second place by this indicator was occupied by Kazakhstan with the number of universities, almost three times less than in Russia. Only two Belarusian universities were awarded the QS rating, while in Armenia and Kyrgyzstan, no higher education institutions were included in this rating.

$\$$ In this case, the average distance is calculated as the average value of all distance measurements from a certain point which corresponds to a particular country to all other points that represent remaining EAEU countries under consideration.
} 


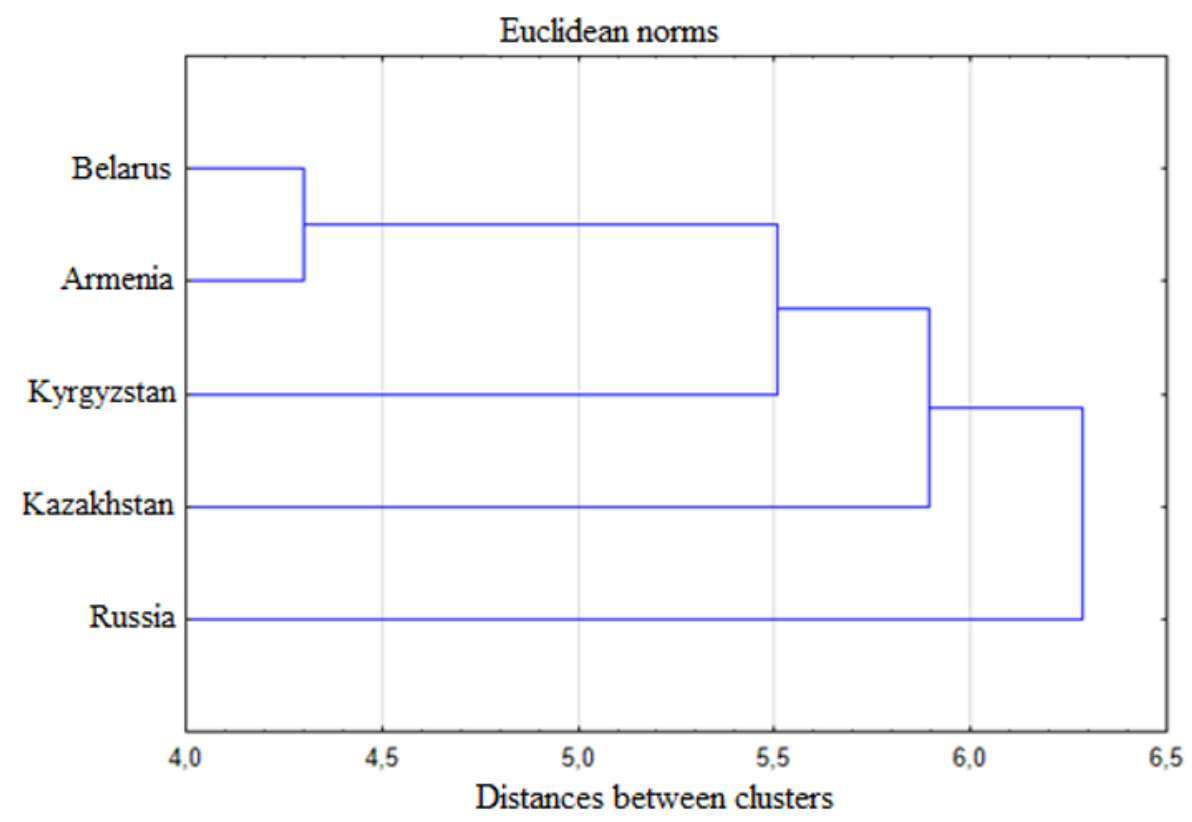

Fig. 1. Dendrogram for the five EAEU countries. Source: Compiled by the authors.

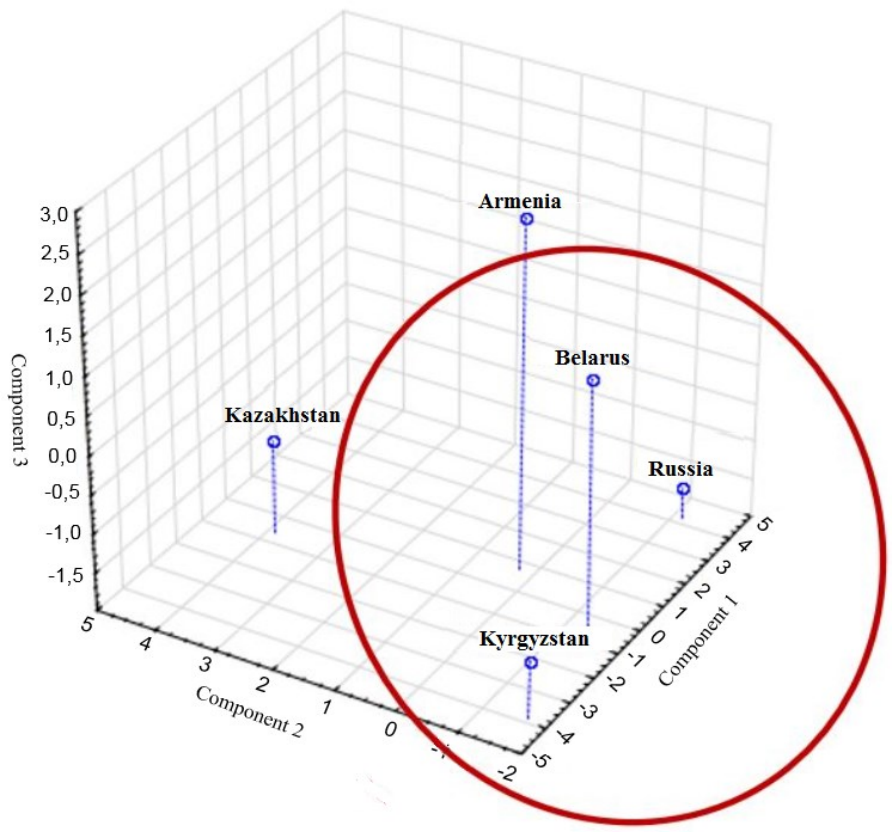

Fig. 2. The scattering diagram for the first three principal components when analyzing the complete set of characteristics. Source: Compiled by the authors.

\section{Conclusion}

The study conducted by the authors has allowed drawing the following conclusions: 
1.Based on the qualitative parameters of the national education systems, Belarus, Armenia, Kazakhstan, and Russia can be integrated into a single cluster, from which Kyrgyzstan is excluded.

2. While taking into account the whole set of parameters of higher education systems, integration for cooperation with Belarus, as well as with Armenia and Kazakhstan will be the easiest and most profitable for Russia.

3. All the EAEU member states have similar approaches to the organization of the higher education system and can hypothetically be integrated into a single educational cluster within the framework of a single Eurasian educational space.

\section{References}

1. T.L. Guruleva, Vysshee Obrazovanie v Rossii [Higher Education in Russia], 12, 134 140 (2014)

2. A.V. Panibrattsev, Nauchnyi Vestnik MGTU GA [Scientific Bulletin of MSTU CA], 203, 49-55 (2014)

3. E.V. Nuzhdaeva, Vysshee Obrazovanie v Rossii [Higher Education in Russia], 7(214), 120-124 (2017)

4. I. E. Zadorozhnyuk, V. M. Kalashnik, S. V. Kireev, Vysshee Obrazovanie v Rossii [Higher Education in Russia], 27(6), 31-40, (2018)

5. R.A. Abramov, S.V. Derevyanko, Modern Education, 1, 39-46 (2017). https://doi.org/10.7256/2409-8736.2017.1.20549

6. I. Stukalova, A. Shishkin, A. Stukalova, Economics and Sociology, 8(1), 275-286 (2015). https://doi.org/10.14254/2071-789X.2015/8-1/21

7. I.B. Stukalova, Bulletin of the Mari State University, 3(27), 40-47 (2017)

8. L.N. Garusova, A.E. Sukhaya, The Herald of Vladivostok State University of Economics and Service, 2, 9-18 (2014)

9. T.F. Kriaklina, Vestnik Altayskoy Nauki [Altai Science Bulletin], 3-4(25-26), 281285 (2015)

10. L.N. Glebova, Science and School, 4, 52-59, (2016)

11. A. V. Akulshina, L. A. Zavialova, Vysshee Obrazovanie v Rossii [Higher Education in Russia], 27(8-9), 117-125 (2018). https://doi.org/10.31992/0869-3617-2018-27-8-9$117-125$

12. T. L. Guruleva, Vysshee Obrazovanie v Rossii [Higher Education in Russia], 27(12), 93-103 (2018). https://doi.org/10.31992/0869-3617-2018-27-12-93-103

13. T. L. Guruleva, N.I. Bedareva, Vysshee Obrazovanie v Rossii [Higher Education in Russia], 28(4), 108-123 (2019). https://doi.org/10.31992/0869-3617-2019-28-4-108123

14. I.V. Ryzhkova, A.M. Sergeev, Vysshee Obrazovanie v Rossii [Higher Education in Russia], 28(3), 127-136 (2019). https://doi.org/10.31992/0869-3617-2019-28-3-127136

15. D.R. Giniyatullina, Problemy Sovremennogo Pedagogicheskogo Obrazovaniya [Problems of Modern Pedagogical Education], 52(6), 24-37 (2016)

16. G.N. Motova, Vysshee Obrazovanie v Rossii [Higher Education in Russia], 27(11), 921 (2018). https://doi.org/10.31992/0869-3617-2018-27-11-9-21 